\title{
Remembering Beirut: Lessons for Archaeology and (Post-) Conflict Urban Redevelopment in Aleppo
}

\author{
Caroline A. Sandes
}

University College London

\begin{abstract}
The reconstruction of central Beirut after the Lebanese civil war by Solidere is not generally considered a success. It has resulted in a soulless, expensive and exclusive area aimed at tourists and wealthy overseas business people who have generally failed to materialise; local people tend to go elsewhere, except when protesting (Ilyés 2015). Despite the fact that Beirut was known to be an ancient city with occupation stretching back to prehistoric times, the initial post-war plans were for a modern city centre built on a tabula rasa. Little thought was given to any cultural heritage. Subsequent protest at this planned destruction ensured changes to the original redevelopment plans to incorporate historic building conservation and some archaeological investigation but it was far from ideal, and often became tangled in the ongoing politico-religious conflicts (Sandes 2010). Aleppo is another such city; occupation can be traced back to the $10^{\text {th }}$ century BCE, and its old city has World Heritage status. The ongoing Syrian war has caused dreadful destruction of the city and its peoples, but in the rebuilding how important will this cultural heritage be considered?

This paper examines the role of the built heritage, particularly archaeology, in the (post-) conflict urban reconstruction process and with reference to Beirut, examines what archaeology has the potential to offer to the rebuilding and rehabilitation of Aleppo and its communities.
\end{abstract}

Keywords: Aleppo, Beirut, sustainable redevelopment, cultural heritage, conflict/postconflict, archaeology.

\section{Introduction}

Aleppo and Beirut are some of the oldest continuously occupied urban areas in the world. Situated on the ancient trade routes from the east, Aleppo in particular was at a cross roads. The legacy of these long and distinguished histories is a wealth of cultural heritage and multi-cultural and -denominational inhabitants. Tragically something they also now share is division and complete devastation due to civil war. Beirut during the Lebanese civil war (1975-1989) became divided between east and west Beirut, with its 
centre a destroyed no-man's land that became known as the Green Line. Aleppo too is divided between the more wealthy government-supporting west and the more poor, rebel-supporting east with central and eastern Aleppo in particular bombed to the point of devastation (Abboud 2016; UNESCO 2017a; Ruck 2016). There seems, at the time of writing, no end in sight of the Syrian civil war that, much as with the Lebanese civil war, has multiple groups of combatants and international intervention that have inflicted terrible destruction and brutality on Syria's civilian population and the tangible and intangible assets of the country, not least its cultural heritage.

This paper is concerned with the built cultural heritage, with a focus on archaeology, and its place within conflict/post-conflict rebuilding and rehabilitation. Despite the many socio-political and economic complexities of cultural heritage, it is crucial that it, in particular archaeology, is a major component of all conflict/post-conflict redevelopment plans.

This paper begins with a brief introduction to the war, and to Aleppo's history and built cultural heritage. It then, via sections on cultural heritage and development and on destruction, taking into account myriad complexities and using Beirut as a case study, demonstrates how crucial, both for archaeology and for communities, its inclusion as a principal component of post-conflict redevelopment plans is.

\section{The Syrian Civil War and Aleppo}

The Syrian civil war ostensibly started as a consequence of poor handling of a protest in Dera'a in the first half of 2011 (Glass 2016: 1). Some teenagers were arrested and tortured for anti-regime graffiti; public protest at their treatment was greeted by security forces opening fire and killing several protesters. From that, Syria began its descent into hell. As with all civil wars, its causes and progress are far from simple and it is much complicated by external factors - the collapse of Iraq and the rise of ISIS to the east; and the involvement of Russia, Iran, US, Europe, Saudi Arabia, Turkey, Kurdish militias and Hizbollah, amongst others, all with their own agendas. This morass has been further aided and abetted by an ethnic and religious mix that should really be, and has been, one of the Syria's crowning glories, but historically toyed with and weakened by colonial violations and ineptitude, and poor government (Watenpaugh 2006: 139) . In further suffering the consequences of globalisation, neoliberalism and inequalities, Syria finally fractured and exploded under the strain (Glass 2016).

Aleppo, initially, did not become involved with the war. The uprising against the government was not universally popular. Aleppo, with its cosmopolitanism and relative prosperity, felt it could avoid the violence and up to early 2012 it had done so (Glass 2016: 114). On the $19^{\text {th }}$ July 2012, fighting broke out between government and rebel forces in the southwest of the city. From then on the city was subjected to severe bombing, battles, besiegement that left tens of thousands dead, injured or displaced, caught between rebel and government forces and their various supporters. 
The toll on Aleppo's built cultural heritage has been equally catastrophic. The initial 'Battle of Aleppo' of July 2012 left central Aleppo with considerable destruction, and this destruction has been ongoing. The souqs, the Umayyad (Great) Mosque, the Citadel have all suffered. The whole central old town of Aleppo was inscribed on the World Heritage list "in recognition of its "rare and authentic Arab architectural styles" and its testimony to the city's cultural, social, and technological development from the Mameluke period(UNESCO 2012); its destruction is considered universally tragic.

\section{History, archaeology and built heritage of central Aleppo}

As mentioned, Aleppo vies for one of the oldest continuously inhabited cities in the world. Cross-roads is the adjective most commonly used when describing Aleppo's past. It is situated between the northern stretch of the Euphrates and the Mediterranean, making it an intrinsic part of the trade routes from the east. It was only in 1938 that it lost its seaboard hinterland and port when France ceded the 'Sanjak of Alexandretta' (Iskenderum) to Turkey (Mansel 2016: 50), extending Turkey's border in a loop southwards to claim that northeast corner of Syria. Aleppo was first mentioned in the tablets of Ebla at Tell Mardikh (2250 BCE) as 'Halab' (Hadjar 2000: 1). Since that time the Hittites, Persians, Greeks, Romans, Arabs, Mongols, Mamluks, Ottomans and French have all ruled over the city (Busquets 2005). The Hellenistic period is still somewhat evident in the gridiron plan in the walled southwest corner of the old city extending around AlAqaba and al-Jallum between the citadel and Bab Antakya. Al Aqaba and al-Jallum are some of the oldest parts of the city within the walls, dating from the Seleucid period of the third century BCE. The city was known as 'Beroea' during the Roman and Byzantine periods; the Via Recta ran from the citadel west to Bab Antakya. The Agora and temple were the subsequent site of the Umayyad Mosque and Madrassa Halawiya; the latter still contains evidence of the Byzantine cathedral, originally built in the fifth century (Hadjar 2000: 2, 138; Gonnella 2008: 13). The Souqs likewise developed from the Agora, later the Umayyad Mosque, towards Bab Antakya.

Aleppo's destruction during the current war is not the first time. The Byzantine emperor Nicephorus Phocas burnt Aleppo and the souqs in CE 962 but they subsequently redeveloped, prospered and expanded. The Mongols under Hulagu also caused much destruction in 1260. Tamerlane destroyed the city in 1400 but the Mamluks rebuild it almost immediately. A savage earthquake in 1822 killed 15000 people and destroyed twothirds of the housing, though once again Aleppo was rebuilt.

The old town, prior to the current conflict was still walled and full of architectural gems dating from the Ottoman period back to medieval and earlier periods, as Hadjar's (2000) guidebook, Historical Monuments of Aleppo, demonstrated. The old town, along with the citadel was designated a World Heritage Site in 1986 in response to the threat of development that had already caused some destruction in the Bab al-Faraj district in the northwest corner of the walled town. Conservation work has been carried out elsewhere in the old city and in the Citadel. Two areas of old Aleppo that have been excavated are the Citadel and Bab al-Faraj. 
The Citadel is a colossal monument, about $550 \mathrm{~m} \times 350 \mathrm{~m}$ at its base, and about $38 \mathrm{~m}$ 'over the city level' (Tawakalna \& Sharaf 2005: 7) larger than that of either Cairo or Damascus, and has produced archaeological remains that date back to the middle of the third millennium BCE in the early Bronze Age. Evidence of a temple of the Storm God, Hadda, as mentioned on the Ebla Tablets, has been uncovered within the Citadel (Kohlmeyer 2009: 191), and the Citadel has been in use in one form or another virtually ever since. Most recently the Citadel was part of a large citadels renovation project (along with those of Masyaf and Salah al-Din) carried out by the Aga Khan Trust for Culture under a Memorandum of Understanding with the Directorate General of Antiquities and Museums in Syria signed in 1999, and with additional funding from the World Monuments Fund (Jodidio 2011: 254). This work, begun in 2000, was unfinished in 2011 when the Syrian civil war broke out. Since then, the Citadel has suffered bomb damage, and has been used as base by snipers (Porter 2016). The excavations lost their protective coverings and the museum on the site was broken into (Franceinfo 2016).

One of the other areas that has been excavated is Bab al-Faraj. Bab al-Faraj is an area in the northwest corner of the walled city, named after one of the gates in the wall at this point. A feature of the area is the Bab al-Faraj clock tower - a ubiquitous element of Ottoman urban architecture - built in 1898-1899 by an Austrian, Aleppo city's architect, Charles Chartier, and Syrian engineer Bakr Sidqi (Archnet 2016). In the late 1960s a plan was put forward to develop high rises in the area, in conjunction with other modernistinfluenced developments that were going on in the city, such as the construction of wider roads, often to the detriment of the historic fabric. After some controversy, the calling in of specialists from UNESCO and elsewhere, and several revisions a third Bab al-Faraj plan was decided upon, not least because in the process of some demolition in that quarter in 1983 as part of the redevelopment, foundations of the old city wall had been found. The Department of Antiquities got there in time to save some of it and it was decided to conserve this in situ (Bianca 1987: 28). The subsequent development of Bab alFaraj, based on this third UNESCO-influenced plan was considered to reflect a 'significant change in attitude' and mark an 'end of crude redevelopment policies, which used to imply the total demolition of complete historic districts and their replacement' (Bianca 1987: 26). It also led to a successful campaign by the Department of Antiquities to get the old town of Aleppo listed as a World Heritage site in 1986. Nonetheless, some demolition still happened, and tall buildings did still blight some of the old architecture, such as the eighteenth century Beit Rajab Pasha and the Al-Dabbagha al-'Atiqa mosque with its twelfth century and later features, of the area (Hadjar 2000: 60).

\section{Cultural Heritage and Development}

Research has consistently demonstrated the importance of cultural heritage to people in terms of sense of place, history, memory and identity, and as a means of facing the future (Ashworth et al 2007; Wedgwood 2009). In conflict/post-conflict situations, the importance of cultural heritage as a vital 'thread of continuity' between the past and an uncertain future is especially important (Stanley-Price 2007, 1; Ascherson 2007; De Jong \& Rowlands 2008). Furthermore it is considered as an 'essential element of a community's 
identity in the building of lasting peace and reconciliation' (UNESCO, UNPF \& UNDP 2015: 77). Specifically, the values of urban heritage are no less. In 2011, UNESCO published its Recommendation on the Historic Urban Landscape, opening with the facts that, firstly, historic urban areas are 'among the most abundant and diverse manifestations of our common cultural heritage' constituting primary evidence of generations of our 'endeavours and aspirations through space and time'. Secondly that urban heritage is a social, cultural and economic asset defined by and representing layers of historic values and cultures, and accumulations of traditions and experiences, recognizable in their diversity (UNESCO 2011).

In some ways, these values have been understood and have been recognised since at least the end of the second world war when, in the aftermath of the destruction of Warsaw by the Nazis, a sociologist commented that if Warsaw and its community were to be re-established, then they had 'to be given back their old rebuilt Warsaw to some extent', and that ' individual attachment to old forms is a factor of social unity' (Stanislaw Ossowksi in Jankowski 1990: 84).

In conflict and post-conflict situations, however, the focus tends to be on nationally and internationally important cultural heritage that is considered to represent the collective identity and which is usually centred on objects of 'high art', in other words major historic and religious buildings, works of art and monuments. This can often be driven by international interest in and therefore potential funding for, for example, World Heritage sites. This is demonstrated in, for instance, in the funds to rebuild the Stari Most, Mostar, coming from the World Bank, UNESCO, the Aga Khan Trust for Culture, and the World Monuments Fund (Armahly, Blasi \& Hannah 2004: 7).

These major monuments and objects of 'high art' often overshadow the cultural heritage of social or anthropological identity or 'the culture of daily life' (Ascherson 2007: 17), and as a consequence a division can develop between the two, with the latter often accorded little if any importance in rebuilding. Cultural heritage, particularly urban heritage, is often overlooked, dismissed as a luxury, or considered a hindrance to redevelopment plans in the rush to stabilise and rebuild post-conflict societies (Barakat 2007), as clearly seen in the redevelopment of central Beirut (Sandes 2010); local urban cultural heritage suffers considerably in this.

Ideally, post-conflict redevelopment is a developmental process requiring long-term commitment and investment, where the priority is not so much physical reconstruction but the restoration and growth of the capacity of people and institutions, and the recovery of society economically, socially, politically and psychologically (Barakat \& Chard 2010: 174; Barakat 2010: 269). The Organisation for Economic Cooperation and Development's guidelines for the prevention of violent conflict also argue for the importance of thinking long-term; for the reinforcement of local capacities, which should be supported, not supplanted, by international aid, and for security where security is not just military security but an overall security that ensures and protects the well-being of people (OECD 2001: 24, 26, 37). 
In the same vein, and following on from the Millennium Goals, is the Post-2015 Dialogues on Culture and Development, a report produced jointly by UNESCO, the United Nations Population Fund and the United Nations Development Programme (UNESCO, UNPF \& UNDP 2015). It draws upon a 2013 UN resolution (A/RES/68/223; UN General Assembly 2013) that acknowledges the direct link between culture and the three components of sustainable development - i.e. economic, social and environmental - and that culture can both drive and enable sustainable development. It also, importantly, acknowledges the role culture plays in inclusion and reconciliation. The Post-2015 report is based on national consultations in 2014 in Bosnia and Herzegovina, Ecuador, Mali, Morocco and Serbia. In addition it includes the results from a call for papers and ediscussions that provided 139 papers and 72 e-discussions from a variety of NGOs, universities, governments, professionals and the private sector from all over the world and covering all the required themes (UNESCO ,UNPF \& UNDP 2015: 10). One of its key points is how culture (which it defines as 'the set of distinctive spiritual, material, intellectual and emotional features of a society or a social group', as per the UNESCO Universal Declaration on Cultural Diversity of 2 November 2001; UNESCO, UNPF \& UNDP 2015: 8, fn 2) aids in strengthening capacities and inclusion. Many of the 'dialogues' received stressed that because of the 'huge amount' of cultural diversity among people, 'blanket approaches' to development were not effective, failing in particular in regions across the world that appear to lag behind, and that there needed to be a move away from the 'one size fits all' approach not only to ensure local realities be taken into account and that the many different and sometimes marginalised stakeholders be included but to ensure that the multifaceted requirements of sustainable development are met. The research demonstrated how culture contributes to more inclusive and sustainable urban development and how traditional knowledge and management practices greatly contribute to enhanced environmental protection and more resilient communities' (UNESCO, UNPF \& UNDP 2015: 16).

One of the report's key messages is how culture reaches out to those not in education, and provides institutions and opportunities for lifelong learning. It mentions how libraries and archives can provide access to primary resources of historic information, and how by using these, this can help teach critical thinking, to recognise historiographical bias and interpret evidence, and help students to develop a balanced approach to history. The importance of this in conflict and post-conflict situations is crucial (UNESCO, UNPF \& UNDP 2015: 34). Education and cultural awareness is a vital component in building cross-cultural understanding, tolerance and inclusion. Likewise museums and the built heritage, assuming they are accessible and provided with signage and information, are crucial in this role. In Northern Ireland the Northern Ireland Heritage Service has worked to present historically divisive sites, such as Carrickfergus Castle, Co. Antrim, in a way that includes, interests and encourages both communities by presenting the sites' histories in a neutral and engaging manner (Hamlin 2000).

Cultural heritage, especially the built heritage, also has a major role to play in sustainable cities and in the counterbalancing of some of the issues of rapid urbanisation. One of the Post-2015 report's key messages is that planning and development that integrates cul- 
ture increase economic opportunities and enhances the quality of life in urbanizing areas; and that culture can transform public spaces into places of dialogue, and can contribute to reducing inequalities and to fostering social inclusion (UNESCO, UNPF \& UNDP 2015: 48).

Such thinking and the social and economic benefits of urban cultural heritage and its restoration and maintenance have been successful demonstrated by projects such as those run by the Aga Khan Trust for Culture's (AKTC) Historic Cities Programme in Africa, Europe and Asia, and by smaller projects such as the independent but similar Turquoise Mountain Foundation (TMF) programme in Afghanistan, and Riwaq in the West Bank, Palestine.

The AKTC's Historic Cities Programme's 'integrated development area concept' links socio-economic development initiatives to urban rehabilitation, conservation and adaptive re-use projects in order to maximize long-term socio-economic benefits for the local communities (AKTC 2007a: 7). Their urban regeneration work in Kabul, for example, has benefited over 30,000 residents and provided 365,000 workdays of skilled and unskilled labour. As part of this, over 150 young men have undertaken apprenticeships as carpenters, masons and plasterers, working alongside highly skilled Afghan craftsmen, and over 2200 local women have attended courses in tailoring, embroidery and kilimweaving, along with literacy classes (AKTC 2012: 1).

The TMF does something similar; it works to revive traditional Afghanistan crafts such as pottery, calligraphy, woodworking and those needed to restore and build traditional architecture, which is mostly mud-brick and timber. In the process of restoring a very run down and threatened historic area of old Kabul, Murad Khane, they have put in running water and electricity, a primary school, health clinic and generated training and employment for both men and women. The products of the re-established crafts are now available for sale via the website or in places such as the shop in the British Museum, as part of the move towards sustainability (TMF 2016).

In the West Bank, Riwaq, set up in 1991 and also an NGO, has been doing something similar. It has established a national register and online archive of historic buildings, helped to restore community spaces and villages and in the process has generated jobs and future opportunities (Ju'beh 2009).

These projects are long-term and relatively low-key, and they involve the local people from the outset. They focus on the locality as a whole and use the rehabilitation of the cultural heritage, both tangible and intangible, to aid both the rehabilitation and sustainable development of the local community, and not simply as a tourist attraction. They don't subscribe to the kind of market-orientated, globalised neoliberal development that has been part and parcel of international development for some decades now, and support the change of thinking on neoliberalism that has begun. Most recently the International Monetary Fund published a paper from their research unit pointing to some of the flaws in neoliberalism, arguing that it has increased inequality and consequently had a 
negative effect on sustainable growth (Ostry et al 2016: 39). The World Bank also argues that heritage is an economic asset, and is cultural capital, much as the environment is natural capital; that it contributes to urban liveability, and therefore attracts talent, and directly and indirectly provides job creation (Licciardi \& Amirtahmasebi 2012). It does, however, highlight the problems of gentrification and the negative effects this can have on lower-income groups. One of the ways to counteract this to take into account the distributional effects at an early stage of the planning, and to involve long-term residents as stakeholders (Licciardi \& Amirtahmasebi 2012: xxiv). More specifically, cultural heritage is now fully recognised at an international level by the UN and World Bank as being a fundamental part of sustainable development, particularly of urban areas.

Likewise, urban archaeology has a role to play in sustainable cities and in the supporting of social values and the provision of capacity-building, education and in the development of community. Archaeology has a crucial part to play in aiding the development of resilience both of cities and their inhabitants; it has a particular ability to engage with narratives of place and via these with community engagement (Williams 2015: 19, 21). Like archives, archaeology also provides primary sources of historical information, and if treated in an impartial manner, can also help in objective cultural and historical education.

In Beirut, once archaeology was included in the post-conflict redevelopment, the excavations achieved many positive things (Perring 2009: 309ff). It has been suggested that the archaeological work helped bridge the gap between the destruction and the rebuilding; that it encouraged people back to the city centre in the provision of work and in the general interest in new discoveries. It also helped people 'reclaim' their city centre and help to rebuild civic pride and sense of place. It allowed Lebanese students and workmen from different factions to work together, and provided opportunities for training and capacity building (Perring 2009). Archaeological investigation continued, virtually all done by and providing work for Lebanese archaeologists (Lawler 2011). Some of the sites excavated in the immediate post-war period were subsequently conserved in situ allowing for an historical identity and point of reference (Sandes 2010; Williams 2015: 22).

All of this is not to deny that archaeology encounters the same problems as other aspects of cultural heritage in terms of politicisation and misuse. It can be equally used to support or foster division, as is discussed in relation to Beirut later on. Archaeological remains may be actively interpreted or even destroyed to support a single usually nationalistic narrative and in the process deny or denigrate the existence of other legitimate narratives, as seen for example in the conflict between Serbia and Kosovo in relation to Kosovo's historic existence (Defreese 2009: 260). It is perhaps most clearly demonstrated in Israel and Palestine, for example in the destruction at Tell el-Rumeida (ancient Hebron) in 2001 due to illegal Jewish settler activity (Rjoob 2009: 219). A notorious example is the site identified as the 'City of David' in Silwan in East Jerusalem. Silwan is a densely-inhabited primarily Palestinian area of which part has been expropriated by an archaeological excavation site managed and controlled by Elad, a Jewish settler organisation, and sanctioned by the Israeli state. The focus is exclusively on Jewish heritage and 
on underpinning the narrative of being the original occupiers of the locality, while simultaneously denying the historic Palestinian habitation of the area (Mannergren Selimovic\&Strömbomb 2015: 191, 197). Jewish settlements and amenities have been built right on the edge of the archaeological site and specific archaeological remains have been conserved and highlighted to suggest a continued connection to the biblical lands (Pullan \& Gwiazda 2009: 33).

Archaeology in the Middle East is further complicated by having its roots in colonisation and western interest in classical and biblical archaeology that, historically have overridden that of, for example, Islamic-period archaeology; archaeology came to be considered as something of relevance to foreigners rather than local peoples (Silberman 1991; de Cesari 2010: 621; Gillot 2010: 4). This problem has been, perhaps inadvertently, perpetuated by who is funding archaeological and other cultural heritage work, particularly if they are international funding bodies or NGOs, as has been argued by Hammami (2012) in looking at the work of such NGOs in Nablus and elsewhere in Palestine. In order to attract funding from international agencies, conservation projects often, ostensibly at least, focus on that heritage that is more attractive to such agencies - usually that which makes reference to western heritage (Hammami 2012: 245; de Cesari 2010: 628). This has led to complaints from Palestinians, both heritage specialists and local people, that the Occupation and colonisation eras should be documented, and that the focus has been on public buildings and tourists rather than on the homes of local people and more recent heritage (Hammami, 2012: 245, 248ff).

\section{Cultural Heritage and Destruction}

All of the values and benefits of cultural heritage generally, and of archaeology specifically, along with the consequences of their loss are equally if not more so, understood by those who deliberately set out to destroy cultural heritage both during and after conflict most often as a form of ethnic or cultural cleansing, This applies as much to major monuments and important historic buildings as it does to local urban heritage. Urban cultural heritage suffers particularly from deliberate destruction for the precise reason that destroying buildings that represent a community and their identity is a means of attacking that community. It is often a component of ethnic cleansing or genocide (Bevan 2007: 8, 14), as was demonstrated in the Balkan wars of the 1990s, and indeed by ISIS in their treatment of, for example, the Yazidis (Sands 2016; Keller 2015). In the ongoing wars of Iraq and Syria, cultural heritage particularly of minorities has been deliberately targeted, most notably by ISIS. This intentional destruction has been labelled 'cultural cleansing', which is defined as 'an intentional strategy that seeks to destroy cultural diversity through the deliberate targeting of individuals identified on the basis of their cultural, ethnic or religious background, combined with deliberate attacks on their places of worship, memory and learning'(UNESCO 2014: 3). Deliberately destroying cultural heritage is also a component of urbicide, defined as 'the destruction of buildings not for what they individually represent (military target, cultural heritage, conceptual metaphor) but as that which is the condition of possibility of heterogeneous existence' (Coward 2009: 39). The destruction of central Beirut happened almost immediately the war broke out; the majority of the destruction and the dividing of the city happened between April 
1975 and November 1976, and it has been argued that this was a case of urbicide (Fregonese 2009). Beirut, prior to the war, had developed an image of a Paris of the Mediterranean with its wealthy and comparatively liberal lifestyle enjoyed by a multiconfessional and multi-ethnic population. Central Beirut, in particular Martyrs Square with its cafes, cinemas and other places of entertainment, epitomised this heterogeneous existence, and seems to have been deliberately targeted. Historic structures such as the old souqs, the $12^{\text {th }}$ century $\mathrm{Al}$ Omari Mosque (formerly a Crusader church), and other historic buildings were destroyed or badly damaged in the process, apparently deliberately so in at least some cases (Sandes 2013: 304).

But deliberate destruction, even urbicide, can be continued by the post-conflict redevelopment process both for the same reasons that it was carried out during the conflict and as a result of the failure to properly protect and manage cultural heritage within rebuilding and redevelopment. In examining an environmental catastrophe, it has been suggested that the ability of the effected community to resist unwanted development or intervention is considerably weakened (Pyburn 2014: 230). In fact, it has been argued that an environmental disaster can create an 'aperture' - a context in which 'the state, foreign investors, and transnational corporations step into a post-disaster space and quickly remake the damaged or threatened landscape to suit their purposes and desires' (Rebecca Zarger in Pyburn 2014: 230). The same can be said for communities that have suffered intensive armed conflict, particularly in urban areas. Due to the vagaries of international donor and media interest, post-conflict redevelopment often replicates short-term refugee assistance projects that focus on 'lower order deliverables and measurable outputs' rather than long-term development programmes (Zetter 2010: 158, 160). There is no place for the immeasurable and the intangible, for example social recovery. As a consequence, the local community is often ignored and considered 'a liability to be neutralised rather than an asset to be utilised' by the international agencies involved in the reconstruction (Barakat 2010: 253). This is further compounded by the fact that many countries that have suffered conflict in the last twenty years or so have also had low levels of development. International assistance has been focused on a 'development-as-usualapproach' that is insufficient to tackle the complex needs of such situations (del Castillo 2011: 2). Furthermore, such development tends to be based on globalised neoliberal policies that favour gentrification (Slater 2009: 298): damaged and overcrowded historic urban areas have been denigrated as slums needing complete redevelopment while other built cultural heritage has been considered only as part of place- and tourist industrypromotion. This is exemplified in a 2007 UN Habitat Report on Iraq's cities that referred to deteriorated historic areas, including Baghdad's historic medina, as slums (UN 2007: 6, 95) and then to Baghdad's '93 archaeological sites and 12 historic buildings' only under 'Tourism Potential' (UN 2007: 126). The results of such policies are often severely detrimental to the uniqueness of a place's cultural heritage, and to existing communities (Kaminer et al 2011: 12). One of the criticisms of the rebuilding of Sarajevo, for example, which has left it with massive unemployment, increasing ethnic division, corruption and cronyism, was the tendency, by both national and international organisations, to view the rebuilding of Sarajevo only in physical terms. Amongst the things ignored by this attitude was culture; there was little if any funding for cultural locations or events. 
Monuments around the city became tied into memorialization of the war and subsequently added to the post-war segregation (Lamphere-Englund 2015: 7).

\section{Between Idealisation and Destruction: Beirut's Archaeology}

The redevelopment of central Beirut (BCD) demonstrates a lot of these problems. Planned as a neoliberal regeneration project, the result is an upmarket tourist, shopping and business 'destination' that has, it is argued, excluded most of its original inhabitants and has lost much of its cultural identity (Cooke 2002; Schmid 2006; Ragab 2011; Ilyés 2015). The Ta'if Accord that stopped the war put in place a policy of amnesty and amnesia because politically there was a strong desire to move on from it. Facing the immediate past is something of a 'politician's phobia' (Seif 2009: 289), and indeed Rafiq Hariri, as prime minister, at a ceremony commemorating the twenty-fifth anniversary of the start of the war, in 2000, declared that not a single building should be kept that would remind people of the civil war as there should be no need to preserve such a painful memory (quoted in Becherer 2005: 18).

The rebuilding of central Beirut was a highly complicated affair politically, financially, socially, practically (Sandes 2010: 84ff; Gavin 2015: 51). The aim had been to restore it as the financial and commercial centre that it had been prior to the war, and there was great significance attached to its rehabilitation. It was thought that this would restore Beirut's historical role as a centre for trade, skills and financial services, re-establish its international standing and act as a kind of magnet development for the rest of the country (Schmid 2006: 366; Al-Hayat 19/05/93 in Diab 1999: 1). For a variety of reasons, not least the region's instability and conflicts, this has not happened.

Planning for central Beirut's rebuilding begun as early as 1977 when the newly formed governmental body, the Council for Development and Reconstruction (CDR) put forward a plan that aimed to re-establish the BCD as a place for all of Lebanon's communities and to retain Beirut's historic Mediterranean and eastern character. This, though, was followed in 1983 by a master plan commissioned by Hariri's engineering company, OGER Liban. Hariri was Lebanese but had made his fortune in development in Saudi Arabia, and it was this company with Dar al-Handasah and Solidere (Société Libanaise pour le Développementet la Reconstruction du Centre-Ville de Beyrouth) that was to ultimately oversee the redevelopment of the BCD (Sandes 2010: 80-81).

The original CDR plan was soon forgotten, and indeed unofficial 'cleaning up' operations resulted in some important historic buildings, including some of the souks, in the BCD demolished as early as 1983, clearly ignoring the recommendations of the CDR plan (Makdisi 1997: 667). In fact post-war plans, beyond some twenty-six religious and government buildings, made no provision what so ever for the cultural heritage in any shape or form, not even for archaeology despite the knowledge from previous excavations and the general history of Beirut that the city almost inevitably sat on significant archaeological deposits. This is not the impression given if one reads anything subsequently about the BCD and its redevelopment written by Solidere, or from a pro- 
Solidere point of view (for example Gavin 2015). The initial plans were for some $80 \%$ of the $\mathrm{BCD}$ to be demolished and rebuilt, and although in the end this is about what was demolished in total, these plans caused outcry and as a consequence the number of historic buildings to be retained was increased to almost 300 (Hamdan 1994; Gavin 1998, 222). The majority of these buildings were, though, within a designated Conservation Area centred on the Place de l'Etoile and the streets of Foch and Allenby. Outside of this area, the emphasis was on clearance and rebuilding (Gavin and Maluf 1996: 53).

In an attempt to do something about the archaeology, international specialists were called in and UNESCO was asked for a report in 1991. After much consultation with Dar al-Handasah, OGER Liban, the CDR, the Department of Antiquities (DGA) and Solidere, archaeological investigation was incorporated into the plans, along with the potential to preserve any significant sites, and finances were made available (Schofield 1992; Sandes 2010: 88).

But the archaeological profession in Lebanon was not set up to deal with large scale developer-led urban excavations, and after fifteen years of civil war the DGA was extremely under-resourced and understaffed. Due to the large scale of the work ahead, the Minister for Culture and Higher Education, Michel Eddé, put out a call for international assistance with the archaeological project. Consequently teams from fifteen different institutions, from Lebanon and from Europe, worked on at least 133 excavations in the BCD area (Ortali-Tarazi 2001-02: 356). Many of the excavations initially doubled as training excavations, for example the American University of Beirut/Leverhulme excavations of the Souks (Perring et al 1996) and the Place Debbas excavations run by a team from the Universities of Freiburg and Berlin (Heinz \& Bartl 1997). There was, though, no overall plan even to coordinate this work; the best that could be done was to establish an overall site numbering system. A UNESCO-commissioned report compiled in 1993 highlighted several issues. One seems to be the overall lack of co-ordination or harmonisation between sites and their directors, added to which there was already a certain amount of intra-archaeological rivalry/resentment developing, which did not help relations with Solidere (Schofield 1994: 6, 12). UNESCO itself also came in for criticism with complaints of being overly-bureaucratic, and of not facilitating communication between the Paris and Beirut offices, nor of any forward planning (Schofield 1994: 13-14).

There are very mixed opinions on Solidere's provision for the archaeological work. Solidere claim that the archaeology, and certainly any sites they considered worth saving, once it became clear that they had no option but to deal with it, were all rapidly incorporated into its plans; areas were made available for archaeological exploration and what they termed a 'strategic approach' was adopted to ensure that every site would be evaluated before redevelopment so that no 'significant' archaeology would be destroyed (Gavin and Maluf 1996: 28; Gavin 2015: 52; Solidere 2016). Indeed, some of the Solidere team were nominally interested, principally Jean-Paul Lebas, then Deputy General Manager, who was supportive from an early stage (H. Seeden pers. comm.). A number of Solidere staff were taken to the Viking centre of Jorvik in York, UK, to demonstrate to them what could be done with archaeological finds in terms of developing a tourist 
attraction, which generated some enthusiasm. Solidere also appointed their own inhouse archaeologist, Dr Hans Curvers. On the other hand, it is suggested that Solidere only took on the archaeological work because not to would be a huge public-relations issue and cause further delay (Sader 2001: 225).

In addition to the practical and professional complications, the archaeology also became caught up in the many political and religious issues. Lebanon is home to about seventeen different socio-religious groups, all of which have their own take on Lebanon's history. It has been argued that one of the causes of the Lebanese civil war, beyond the great disparities of wealth, was a failure to develop a common history (Salibi 1988). Even prior to the war, archaeology and heritage was used to promote a supposed Phoenician identity, and there has been a tendency for some communities to appropriate elements of Lebanon's history and heritage to the exclusion of others; an example being the Maronite Christian claiming of the Phoenician past as exclusively theirs (Seif 2009: 284, 285). These kinds of confessional politics played out in protests about what archaeological remains should be saved or destroyed, and the various factions usually only cared about what they considered to be their heritage, while not caring for anyone else's (Sandes 2010: 89). So protests and the Phoenician element were used to ensure the preservation in situ of, for instance, the Iron Age remains discovered during excavations of the souks site, and of the Ancient Tell and Glacis site, even though settlement of the latter dated to an earlier period (Sandes 2010: 95). The small sixteenth-century Mamluk ribat that survived the demolition and clearance of the original souks buildings is another such example. It was built by Sufi Ibn 'Iraq al-Dimashqi and it was initially considered to be a Shia shrine. Beirut is generally considered to be a Sunni city so it was very important to the local Shia population to have a shrine in the BCD, but the local Sunnis were not happy, and based on their own research decided Ibn 'Iraq was in fact a Sunni from Syria, and claimed it as their own, fencing it off and adding a sign with the 'correct' history (Bercherer 2005: 27). The Mosque Al Omari, originally the twelfth-century Crusader cathedral of St John, was enlarged due to a Sunnite -endowment, which involved deep excavations with no archaeological recording that led to the destruction of RomanoByzantine remains in what has been suggested as a kind of 'purification' of a sacred space (Seif 2009: 286). Something similar happened at the Greek Orthodox St George's Cathedral, where Byzantine remains were carefully conserved but Ottoman and Mamluk archaeological remains were cleared away (Seif 2009: 286). So, rather than there being a commonality of the past, the archaeology was sometimes destroyed by or used to accentuate the socio-religious divisions.

Furthermore, many simply saw archaeology and conservation as political weapon to be used against Solidere and Hariri. There was a tendency to assume the archaeologists were against the development, and that they would support any attempts to halt it, but this was not the case (Seeden 2000: 181). Public support for archaeology and conservation was therefore not straightforward, and many complained bitterly that archaeologists were in fact destroying the heritage, and the usual debates raged as to whether one should work with the developers as better than nothing, or not at all so as not to give them any sense of legitimacy (Perring 2009: 305). Public opinion ranged from the sug- 
gestion that the archaeological discoveries created a new type of exciting and challenging public space (Kabbani 1998: 257), to others arguing that it was the archaeological excavations that were the final element in a systematic erasure of modern Beirut (el-Khoury 1998: 260).

In the end, mostly due to the sheer dedication of the archaeologists involved aided by those who were sympathetic, including some local developers, some archaeology was done and some of the sites were left to be conserved for display, allowing for a sense of Beirut's past, but also a considerable amount was destroyed before anyone could get to it. Some of the conserved in situ sites have been incorporated into a walking trail (Solidere 2016). An area of about a hectare between Martyrs Square and Place de l'Etoile of multi-period archaeological remains was left open to be conserved as part of a Garden of Forgiveness to commemorate the civil war, though that has caused its own controversies and its landscaping and completion is on hold for the foreseeable future (Sandes 2010: 97; Gavin 2015: 60).

Solidere's rebuilding of central Beirut is often considered an attempt to erase Beirut's history (Schmid 2006: 375), and may in some ways be considered an extension of the urbicide inflicted on central Beirut during the war (Sandes 2013: 305). For all intents and purposes, and despite protest, some $80 \%$ of the city centre was demolished in the process of rebuilding, and it was also aimed at a rather homogenous wealthy elite, rather than recreating the heterogeneous space it was before the war. With the exception of the twenty-six religious and government buildings that were to be retained from the beginning, the majority of buildings conserved are Ottoman and French Mandate buildings.

The buildings demolished included much of the architecture of Lebanese architects built between 1940s and 1970s - in other words that which had helped to construct an identity for a young post-colonial republic (el-Dahdah 1998: 73), and very little to remind any one of the civil war beyond the inadvertent 'monuments' of the heavily damaged Murr Tower and Holiday Inn (though the latter is due to be redeveloped). All of the 'memory' has been placed on the non-related archaeological remains of the Garden of Forgiveness, and there is much criticism that the historical image of the BCD is 'saccharine' (Ragab 2011: 110). Some of the uses of the past within the BCD suggest a deliberately selective memory, and also remind one that 'destruction' can be more subtle than a bulldozer. Throsby (2012 118) has defined 'disneyfication' as 'turning the heritage location or site into a consumer-oriented entertainment package - a Disneyland - in pursuit of greater economic profit', and this in itself can hollow out the cultural heritage to nothing more than a mildly attractive and pseudo-traditional/-heritage backdrop.

The BCD has been described as a 'polished mix of restored buildings, ancient ruins and glass towers... and a very costly monument to vanity and self-delusion' (Ilyés 2015), but it is comparatively easy to disparage the BCD redevelopment under Solidere's direction. Regardless of the outcome, it is important to remember that in 1989, a weak Lebanese government had, after fifteen years of a savage war, a thoroughly destroyed and by no means reconciled country to restore and no money to do so. Central Beirut was an over- 
grown wasteland of ruined buildings and rubble; a public private partnership was quite possibly the only way to do it, particularly when being pushed by a successful and wealthy businessman, as Rafiq Hariri was, and there seemed little by way of real alternatives, or rather any opposition to the plans soon disappeared as the media was forced into compliance (Schmid 2006: 376). Angus Gavin (2015: 63), Solidere's head of Urban Development, has acknowledged that redevelopment strategy of the BCD has priced ordinary Lebanese out of the BCD, leaving it the realm of the wealthy, but he suggests that this should not be seen as a failure as many cities develop high-end 'downtowns' which are considered a success. Maybe in time it will be a success, but for a war-torn and socially-divided country and city, the BCD redevelopment was what del Castillo (2011: 2) identified as a 'development-as-usual-approach' that failed to take into account the many social and economic complexities of not only Beirut but of Lebanon as a whole.

\section{Aleppo and Post-Conflict Recovery}

There is no need for this to be repeated in Aleppo, or Homs, or Syria as a whole for that matter. Since the 1990s, and as demonstrated above, cultural heritage has come to be widely appreciated as a fundamental social value, even right, and an asset, combined with an understanding that its sustainable rehabilitation as a whole, rather than just prominent sites and buildings, comes part and parcel with the local people and their rehabilitation and sustainability. Projects such as the AKTC Historic Cities projects referred to previously are a positive demonstration of this.

Furthermore, while in the 1980s when Beirut was a war zone, Aleppo was repelling the Bab al-Faraj redevelopment project that was threatening to demolish a significant amount of this quarter of the historic city. By 1986 the Syrian Department of Antiquities and others had succeeded, mostly, and had got the old town listed as a World Heritage Site. Since then there have been other conservation projects in the city, not least the Citadels programme. In other words, Aleppo already has some history of protecting archaeology and conservation in the face of aggressive development. Furthermore, the Syrian Directorate-General of Antiquities still has a staff of 2,500 with 500 architects and engineers (Abdulkarim 2016: 10). Lebanon's DGA in 1990 had four members of staff (Sadar 2001: 224). That is not to say help is not needed; restoring Aleppo's cultural heritage alone will be a colossal job, not to mention that of the rest of the country, and the Director-General of Antiquities and Museums of Syria, Dr Maamoun Abdulkarim has urgently called for international help (2016: 9).

What perhaps is the same as the Beirut situation is that powerful urban development companies are already circling Aleppo, recognising huge potential for profit in its rebuilding (Fisk 2016). This level of destruction will have created one of Zarger's (in Pyburn 2014: 230) 'apertures' into which foreign investors, corporations and other agencies will pour, but with their profit margins and/or soft power being of primary concern to them. Talks in May 2017 between Syria's minister for culture, Mohammad al-Ahmad, and his Chinese counterpart, Luo Shugang, as part of China's One Belt One Road programme to develop trade and relations in countries along the old Silk Routes have al- 
ready been reported, with Aleppo's cultural heritage being specifically mentioned (Milhem 2017; al-Frieh \& Said 2017). It is likely that the allies of the Assad regime will be most involved in the country's reconstruction, including of Syria's damaged cultural heritage. It has been reported, for example, that Chechnya, who supported Russia and the Assad regime in regaining Aleppo, are providing funding for the restoration of Aleppo's Umayyad Mosque (Geopolmonitor 2017; Suchkov 2017; Fisk 2017). Experience suggests that while large World Heritage and other such important sites may not suffer too much, even gain, from international investment, the more locally-important heritage and in particular the urban heritage will suffer, particularly that which may be considered politically sensitive.

The problem is that the quantities of financial investment required will be staggering. In Spring 2016 the World Bank had already estimated that some US $\$ 180$ billion will be needed to bring back Syria to a pre-war level of GDP (World Bank 2016a), and that in a report of the 1 October 2016, the damage assessment was between US\$5.9-7.3 billion, with Aleppo accounting for almost 60 percent of the damage costs (World Bank 2016b). This is in the face of catastrophic human tragedy - estimates range of the numbers dead to be between 250,000 and 470,000 (World Bank 2016b), not to mention those injured, displaced and who have fled the country all together, and that's before the long-term cost and consequences of collective post-traumatic stress, loss of education and employment and other social problems are taken into account. Resistance to aggressive redevelopment plans that work from the top down will be difficult, but as Dr Abdulkarim (2016: 9) argued, "We refuse to have new hotels, new buildings in this site because, of course, if we do so, the people will ask us: it's finished, you have destroyed everything, why did you rebuild new buildings? It's not an archaeological issue, it's an issue of identity of the city. We cannot leave Aleppo to businessmen."

That the Beirut model should not be followed is also argued by many others, not least the Aleppo Project (Ilyés 2015). The Aleppo Project is run from the Shattuck Center on Conflict, Negotiation and Recovery at the Central European University's School of Public Policy in Budapest. Its aim is 'to gather as much as we can about the past of the city, document the horrors that have befallen it and think about what sort of future might lie ahead'. It is an open, multi-disciplinary collaboration that, thanks to the internet and social media is able to include Syrians, including those still in Aleppo, in its planning for post-conflict Aleppo (Aleppo Project 2016).

At least one redevelopment plan for Aleppo already exists in the form of Aleppo Diverse |Open City: an urban vision for 2025, a pre-war report on the work of a joint undertaking by the Municipality of Aleppo and the German Technical Cooperation (GTZ / BMZ), as part of the Syrian-German Program for Sustainable Urban Development and published in 2010. Its vision was of Aleppo 'as a place that displays the authenticity of a contemporary Middle Eastern city, a place where modernity and a rich cultural heritage do not conflict with each other, but merge into a mutually enriching relationship. The unbowed tradition of openness and coexistence of the local people [is] to be witnessed all over the city' (Saad \& Stellmach 2010: 5). It was coordinated by a German planning 
practice, Uberbau. Mindful of the historic tendencies of western planners imposing their own values onto cities of developing countries and to avoid influencing or defining the objectives of Aleppo's development from the perspective of a foreign practice, Uberbau based the project on the Local Agenda 21 of 2009 and worked from the critical issues then facing the city as identified by working groups of Aleppo's city council (Saad \& Stellmach 2015: 117). From this eight ecological, economic and cultural benchmarks for sustainable development in Aleppo were identified of which the third was 'Preserving and reviving heritage to consolidate the individual's belonging to the environmental and cultural surroundings' (Saad \& Stellmach 2015: 118). While they appreciate importance of cultural heritage and the dangers of disneyfication, they do slip into this unimaginative tendency to see cultural heritage primarily as a tourist attraction (Saad \& Stellmach 2015: 127).

This report was well received by both local and international partners, and seems to offer an example of how foreign specialists and local professionals and stakeholders can successfully work together. The inclusiveness of the project in involving the local communities marked a major positive change in the approach to planning in Syria, and even offered a potential template for other urban centres (Saad \& Stellmach 2015: 128). However, the reasons given for the project not being implemented are telling:

the project ultimately failed to be even partially implemented, most likely because of the resistance of powerful landowners. The Strategy questioned the over provision of developable land, which was apparently driven by speculation interests. Uberbau's clear recommendation to reduce the amount of developable land would have reduced the potential profitability of many properties, probably rendering the public ratification of the amendments to the masterplan impossible. Later in 2010, some of the local actors involved in the Aleppo spatial planning process were detained and questioned concerning illegal land speculation. In an atmosphere of such uncertainty, it very quickly became politically undesirable to be involved with Aleppo's spatial planning in any way, bringing the process to a standstill up until the current civilpolitical crisis emerged. (Saad \& Stellmach 2015: 128).

These kinds of problems so evident before the war (as for example also mentioned by Al-Sabouni (2016)) will not have disappeared with the war. If anything, in the weakened if not destroyed social and physical environment of the post-war situation, they will become worse. In 2015 such concerns were voiced by Mamoun Fansa, a Syrian archaeologist and native of Aleppo now resident in Berlin: 'We cannot stand by until the last embers of the war have died down ... If we don't start with a reconstruction plan now, we'll pay for it for the rest of our lives, because the moment there's a peace agreement, international investors, especially from Saudi Arabia and Lebanon along with corrupt officials from the Syrian government, will pounce on the city and guarantee that Aleppo loses its historical face once and for all' (Connolly \& Bloch 2015). Corruption and postconflict redevelopment is a much discussed subject (for example Cooley \& Marguette 2015).

Beyond the major sites and buildings, it is too easy for cultural heritage to be swept away in such situations, and this is particularly so if it has not been included as a principal 
component of redevelopment plans. The greatest problem for archaeology and cultural heritage in Beirut was the lack of provision for it in the overall plans for the redevelopment of the BCD. By the time it was realised that central Beirut's historic fabric and archaeology were in grave danger, the master plan had already been completed. Although changes were made, there was never going to be sufficient temporal and financial resources to manage the excavations properly, let alone allow archaeology to contribute more fully to capacity building, employment and social rehabilitation.

\section{Discussion}

In January 2017, after Syrian government forces had recaptured the city, UNESCO produced an emergency assessment on the extent of damage to Aleppo's cultural heritage and to its educational institutions, reporting that about 30\% of Aleppo's old town had been totally destroyed, while a further 60\% of it severely damaged (UNESCO 2017a). This assessment was followed by an international coordination meeting convened by UNESCO in Beirut and involving representatives of the Syrian Directorate General of Antiquities and Museums (DGAM), the Aleppo City Council, the Ministry of Tourism, the Directorate of Aleppo Awqaf (Ministry of religious endowments), NGOs and universities to discuss safeguarding and first-aid measures for Aleppo's cultural heritage; the Director of the UNESCO Regional Office in Beirut, Hamed Al Hammami, stressed that 'Syria's national and local stakeholders have successfully started working in a tremendously difficult context, and future recovery and rehabilitation efforts must advance in order, with extreme care and precision.' (UNESCO 2017b).

All this focus seems, however, to be on the World Heritage Site of the Old Town. This, combined with the problem of heritage of certain periods being considered more important than others due to the need to attract international involvement, and due to the potential overemphasis on tourism as a primary reason for conservation, will almost certainly lead to surrounding and more locally important cultural heritage being lost. These problems were referred to earlier in relation to Beirut and Palestine but Wyndham in her work on cultural heritage in Afghanistan has also highlighted these issues. In relation to work in the Bamiyan valley, with an exhibition at the National Museum in Kabul, and at Mes Aynak, there has been an international focus on Afghanistan's pre-Islamic past while simultaneously neglecting the Islamic heritage with seemingly no appreciation of the latter's greater relevance to the Afghans themselves (Wyndham 2015: 122, 128, 132). She notes the lack of 'Afghan agency' in determining conservation priorities and the evident shortcomings of this, though this is something that at last has been realised by UNESCO and is being addressed, for example by work on Islamic sites in the Bamiyan valley (Wyndham 2015: 139).

Despite the precedent of Beirut, there is also a very real danger that archaeology, which tends to get overlooked even if there is a genuine interest in conservation and restoration (there is little mention of archaeological investigations by the Turquoise Mountain Foundation or any of the AKTC projects, for example), will not be fully included. As discussed there are, however, two major problems with the inclusion of archaeology in 
post-conflict rebuilding. The first is well established - that cultural heritage, including archaeological remains, is political, and in terms of economics is often recognised only for its tourism benefits. While both of these aspects can ensure the survival of some material, it can equally lead to destruction of other material, either directly in its removal, or indirectly via neglect or disneyfication.

This leads to the second problem of managing archaeology so that both its core values and is social and economic potential are protected and appreciated but do not come into conflict. Archaeology is primarily about knowledge creation and understanding the past, but this cannot be considered in isolation from local conditions and communities in their widest senses. Archaeological professionals can sometimes exclude or disregard local communities' values of the site, which can range from folklore to economic, seeing them of lesser value to the scientific/academic value, leading at best to a lost opportunity to engage local interest and support and at worst to potential conflict (Orbaşlı 2013: 241; Gillot 2010: 11). In getting the balance right between development at any cost and being against development, it has been argued that heritage professionals in general need to 'reinvent the field of public heritage as a revival of peoples' sense of belonging and participation in a living cultural community, not just the preservation or safeguarding of symbolic heritage elements' (Silberman 2012: 440).

Nor can the practice of archaeology often be separated from archaeologists' and others own priorities and politics. It has been argued that the discipline of archaeology operates almost exclusively within the framework of the nation state which in turn exercises its sovereignty over the archaeological record and therefore over the representation of the past via state departments of antiquities, national museums, education curricula etc., which is difficult to break free of to ensure that what's best for the archaeology is at the core of any work (Stritch 2013: 153, 161). Stritch (2013: 163) argues it is only through long term workable plans that have the archaeological remains at their heart, that the concerns of other interested parties can be protected also. Likewise Orbaşl1 (2013: 251) argues that the tangible economic and social benefits of archaeological sites are best achieved when there is an active excavation, research or conservation plan, with a corresponding management presence, for the site in question. But this requires an objective, egalitarian approach that Stritch (2013) acknowledges is hard to reach within the political confines of the nation-state; this is even more so in the conflict/post-conflict situation as this intensifies these issues.

\section{Conclusion}

As demonstrated, there is no doubt that involving cultural heritage, particularly archaeology, in conflict/post-conflict rebuilding is a highly complex matter, fraught with politics, economics and dilemmas over social, financial and cultural heritage priorities. But what is also demonstrated is the fundamental importance of cultural heritage to society and what cultural heritage, specifically archaeology, can offer in the conflict/postconflict situation. 
It is crucial, however, that from the outset archaeological assessment and investigation be a key component of all restoration and redevelopment plans, whether for, in the case of Aleppo, restoring the Old Town or rebuilding beyond it. There is time, despite the obvious urgency of the situation, to factor in archaeological work: not all sites or areas are going to redeveloped at once or at the same time. Likewise, it can take many months even years to get the larger scale rebuilding programmes off the planning board and into action. It is crucial that archaeological plans and resources be ready to fit into these timescales, so to identify potentially important sites and to make use of sites waiting rebuilding. There is plenty of transferrable experience of successful developer-led archaeological investigation from cities worldwide that could be adapted and utilised. Training programmes, such as that being provided by the British Museum for Iraqi archaeologists (British Museum News 2017), or to that for stonemasons in Aleppo announced by the Syrian Directorate of Antiquities (Heritage for Peace 2017) can be put in place. They in turn could train and involve other local people both to know what to look out for when they are rebuilding their homes or clearing rubble, and to work on excavations and survey. Archaeological excavation is something that can be learned, with skilled supervision, on the job and as well as getting local people involved with their heritage, can generate much needed employment, both for the short and long-term on post-excavation work, as demonstrated in Beirut.

Rather than seeing archaeology as a drain on resources, it should be considered financial investment in job -creation and skills -development, and for all the socio-cultural reasons detailed previously. The challenge is ensuring that archaeology and its core values are a principal part of any reconstruction plan from the outset, and in the case of Aleppo, that applies equally to the plans to restore the Old Town and to rebuilding plans for the wider city.

\section{References}

AbBoud, S. 2016. Syria Civil War: 'the sky is falling' in: Aleppo. Al Jazeera, 3 May 2016. Accessed 10 May 2017

http://www.aljazeera.com/news/2016/05/syria-civil-war-sky-falling-aleppo160503102848888.html.

ABDUlKarim, M., 2016. Challenges facing cultural institutions in times of conflict: Syrian cultural heritage, in: Post-trauma reconstruction: colloquium at ICOMOS Headquarters, Charenton-le-Pont - France, 4 March 2016, volume 2, 9-11. Paris: ICOMOS.

AKTC (Aga Khan Trust for Culture), 2007a. Aga Khan Historic Cities Programme: an integrated approach to urban rehabilitation. Geneva: Aga Khan Trust for Culture.

AKTC (Aga Khan Trust for Culture), 2012. Restoration projects in Afghanistan: project brief 2012. Accessed 3 November 2016. http://www.akdn.org/press-centre/publications.

Aleppo Project, 2016. Accessed 3 November 2016

http://www.thealeppoproject.com/home-inn/.

AL-FrieH, M. \& SAID, H. 2017. Culture Minister discusses cooperation within Belt and

Road initiative with Chinese ambassador. SANA 25 May 2017. http:/ / sana.sy/en/?p=106941 
Al-Sabouni, M., 2016. The Battle for Home: the memoir of a Syrian architect. London: Thames and Hudson

ArCHNEt, 2016. Bab al-Faraj, Aleppo, Syria. Accessed 3 August 2016. http://archnet.org/sites/2875/media_contents/98960,

Armahly, M., Blasi, C. \& HANNAH, L., 2004. Stari Most: rebuilding more than a historic bridge in Mostar. Museum International 56(4): 6-17.

Ascherson, N., 2007. Cultural Destruction by War, and its Impact on Group Identities, in: N. Stanley-PRICE (ed.), Cultural Heritage in Postwar Recovery. Rome: ICCROM Conservation Studies 6, 17-25.

Ashworth, G.J, B. Graham \& J.E. Tunbridge, 2007. Pluralising Pasts: Heritage, Identity and Place in Multicultural Societies. London and Ann Arbor, MI, Pluto Press.

BARAKAT, S., 2007. Postwar reconstruction and the recovery of cultural heritage: critical lessons from the last fifteen years, in: N. STANLEY-PRICE (ed.), Cultural Heritage in Postwar Recovery. Rome: ICCROM Conservation Studies 6, 26-39.

BARAKAT, S., 2010. Seven pillars for post-war reconstruction, in: S. BARAKAT (ed.), After the Conflict: Reconstruction and Development in the Aftermath of War. London \& New York: I.B. Tauris (second edition), 249-70.

Barakat, S. \& M. Chard, 2010. Building post-war capacity: Where to Start?, in S. Barakat (ed.), After the Conflict: Reconstruction and Development in the Aftermath of War. London \& New York: I.B. Tauris (second edition), 173-90.

BECHERER, R., 2005. A matter of life and debt; the untold costs of Rariq Hariri's new Beirut. The Journal of Architecture 10 (1): 1-42.

BEvan, R., 2007. The Destruction of Memory: Architecture at War. London: Reaktion Books.

Bianca, S., 1987. The Bab Al-Faraj project, in Hasan-UdDin KHAN (ed.), Mimar 24: Architecture in Development. Singapore: Concept Media Ltd, 26-35.

BRitish Museum News, 2017. Blog: The Iraqi archaeologists saving their heritage $3^{\text {rd }}$ March 2017.

http://blog.britishmuseum.org/the-iraqi-archaeologists-saving-their-heritage/.

Busquets, J. (ed.), 2005. Aleppo. Rebabilitation of the Old City. Cambridge, MA: Harvard Graduate School of Design.

CONNOLLY, K. \& BLOCH, W., 2015. The war is still raging but the race to rebuild Aleppo has already begun'. The Guardian 12th March 2015. Accessed 3 November 2016 https://www.theguardian.com/world/2015/mar/12/war-rebuild-aleppo-syriaarchitects-reconstruction

CoOley, L. \& MARquetTe, H., 2015. Corruption and post-conflict reconstruction, in: P. JACKSON (ed.), Handbook for Security and Development. Cheltenham: Edward Elgar, 32969.

CoOKe, M. 2002. Beirut reborn: the political aesthetics of auto-destruction. The Yale Journal of Criticism 15 (2): 393-424.

Coward, M. 2009. Urbicide: the Politics of Urban Destruction. London \& New York: Routledge.

Defreese, M., 2009. Kosovo: cultural heritage in conflict. Journal of Conflict Archaeology 2009 5(1), 257-69.

De Jong, F. \& Rowlands, M., 2008. Introduction: postconflict heritage, Journal of Material Culture 13(2), 131-134. 
Del Castillo, G., 2011. The Economics of peace: five rules for effective reconstruction. United States Institute of Peace Special Report 286. Accessed 19 January 2012 http://www.usip.org/files/resources/SR286_The_Economics_of_Peace.pdf DE Cesari, C., 2010. Creative heritage: Palestinian heritage NGOs and defiant arts of government. American Anthropologist 112 (4), 625-37.

Diab, H., 1999. Beirut: Reviving Lebanon's Past. Westport, USA: Praeger Publishers.

DissARD, L. \& HARMANŞAH, O. 2016. IAS Materialities and Technologies Workshop: Archaeology as Salvage Operation in the Middle East - Ethics, Politics and Methods. 10th December 2016. Accessed 11 December 2016

http://www.ucl.ac.uk/institute-of-advanced-studies/ias-events/ias-materialities-andtechnologies-archaeology-as-salvage-operation-in-the-middle-east-ethics-politics-andmethods.

el-Dahdah, F., 1998. On Solidere's Motto, "Beirut: Ancient City of the Future”, in: P. ROWE \& H. SARKIS (eds.), Projecting Beirut: episodes in the construction and reconstruction of a modern city. Munich, London, New York: Prestal, 68-77.

EL-Khoury, R., 1998. Beirut sublime, in P. Rowe \& H. SARKIS (eds.), Projecting Beirut: episodes in the construction and reconstruction of a modern city. Munich, London, New York: Prestal, 260-62.

FISK, R., 2016. Who will fund the dream of rebuilding Syria back to its former glory? Independent $11^{\text {th }}$ June 2016. Accessed 3 November 2016

http://www.independent.co.uk/voices/who-will-fund-the-dream-of-rebuilding-syriaa7076436.html

FISK, R., 2017. Syrians aren't just rebuilding an ancient mosque in Aleppo - they are rebuilding their community. Independent $25^{\text {th }}$ July 2017. Accessed 30 July 2017

http://www.independent.co.uk/voices/syria-great-mosque-of-aleppo-ummayad-rebuildthe-city-a 7858846.html

FrANCEINFO, 2016. Document France 2. Syrie: au cœur de la vieille ville d'Alep, ravagée par la guerre 25 January 2016. Accessed 25 July 2016

http://www.francetvinfo.fr/monde/revolte-en-syrie/document-france-2-syrie-au-coeurde-la-vieille-ville-d-alep-ravagee-par-la-guerre_1284019.html

Fregonese, S. 2009. The urbicide of Beirut? Geopolitics and the built environment in the Lebanese civil war (1975-1976). Political Geography 28, 309-318.

Gavin, A., 1998. Heart of Beirut: making the Master Plan for the renewal of the Central District, in: P. ROwE \& H. SARKIS (eds.), Projecting Beirut: episodes in the construction and reconstruction of a modern city. Munich, London, New York: Prestal, 217-233.

GAVIN, A., 2015. The corporate discourse: learning from Beirut's central area renewal, in: R. SAliBA (ed.), Urban Design in the Arab World: reconceptualizing boundaries. Farnham, Surrey: Ashgate Publishing Ltd, 51-64.

Gavin, A. \& MALuf, R., 1996. Beirut Reborn: the restoration and development of the Central District. London: Academy Editions.

GEOPOLMonitor staff, 2017. Chechan government to restore Aleppo's Great Mosque. GEOPOLMonitor 24 $4^{\text {th }}$ January 2017. Accessed 27 January 2017. http://www.geopolmonitor.com/chechen-government-restore-aleppos-great-mosque/ 
GILLOT, L., 2010. Towards a socio-political history of archaeology in the Middle East: the development of archaeological practice and its impacts on local communities in Syria. Bulletin of the History of Archaeology 20(1), 4-16.

GLASS, C., 2016. Syria Burning: a short history of a catastrophe. London: Verso.

Gonnella, J., 2008. The Citadel of Aleppo. Geneva: Aga Khan Trust for Culture.

HadjAR, A., 2000. Historical Monuments of Aleppo. Aleppo: Automobile and Touring Club of Syria.

HAmDAN, K., 1994. Smart patches, shame about the coat. New Internationalist 258. Accessed01 December 2006. http://live.newint.org/issue258/smart.htm;

Hamlin, A., 2000. Archaeological heritage management in Northern Ireland: challenges and solutions, in F. P. MCMANAMON \& A. HATTON (eds.), Cultural Resource Management in Contemporary Society: perspectives on managing and presenting the past. London and New York: Routledge, 66-75.

Hammami, F., 2012. Conservation under occupation: conflictual powers and cultural heritage meanings, Planning Theory \& Practice 13 (2), 233-56.

Heinz, M. \& BARTL, K., 1997. BEY 024: "Place Debbas": Preliminary report. BAAL (Bulletin d'Archéologie et d'Architecture Libanaises) 2: 236-257.

Heritage for Peace, 2017. Damage to Syria's Heritage, $21^{\text {st }}$ August 2017. Accessed 21 August 2017.

http://www.heritageforpeace.org/syria-culture-and-heritage/damage-to-culturalheritage/previous-damage-newsletters/damage-to-syrias-heritage-21-august-2017/ ILYÉS, I.I., 2015. Rebuilding Downtown Beirut. Accessed 12 May 2016. http:/ / www.thealeppoproject.com/papers/reconstructing-downtown-beirut/ JANKOWSKI, S., 1990. Warsaw: destruction, secret town planning, 1939-44, and postwar reconstruction, in: J.M. DiEfEndorf (ed.), Rebuilding Europe's Bombed Cities. London: Macmillan Press Ltd, 77-93.

Jodidio, P. (ed.), 2011. The Aga Khan Historic Cities Programme: strategies for urban regeneration. London: Prestel.

JU'BEH, N. 2009. Cultural heritage in Palestine: RIWAQ new experiences and approaches. Accessed 23 January 2015.

www.jerusalemsverein.de/downloads/Texte/Cultural_Heritage_in_Palestine.pdf KabBani, O.R., 1998. Public Space as Infrastructure: the case of the postwar reconstruction of Beirut, in: P. ROWE and H. SARKIS (eds.), Projecting Beirut: episodes in the construction and reconstruction of a modern city. Munich, London, New York: Prestal, 240-59.

Kaminer, T, Robles-Durán, M, \& SOHN, H. (eds.), 2011. Urban Asymmetries. Studies and projects on neoliberal urbanization. Rotterdam: 010 Publishers.

KELLER, J., 2015. Why ISIS's destruction of ancient art is more than a war crime. The Daily Dot, $17^{\text {th }}$ March 2015. Accessed 11 May 2017 https://www.dailydot.com/via/isis-war-crimes-genocide-ancient-art/

Kohlmeyer, K., 2009. The Temple of the Storm God in Aleppo during the Late Bronze and Early Iron Ages. Near Eastern Archaeology 72(4), 190-202.

Lamphere-Englund, G., 2015. Rebuilding Sarajevo. Budapest: Centre for Conflict, Negotiation and Recovery, Central European University.

LAWLER, A., 2011. Rebuilding Beirut. Archaeology 64 (4). Accessed 18 November 2016 http://archive.archaeology.org/1107/features/beirut_lebanon_urban_archaeology.html 
LiCCIARDI, G. \& R. AMirTAHMASEBI (eds.), 2012. The Economics of Uniqueness: investing in bistoric city cores and cultural heritage assets for sustainable development. Washington DC: The World Bank.

MAKDISI, S., 1997. Laying Claim to Beirut: urban narrative and spatial identity in the age of Solidere. Critical Inquiry 23 (3): 660-705.

Mannergren Selimovic, J. \& L. Strömbom (2015) Whose place?: Emplaced narratives and the politics of belonging in East Jerusalem's contested neighbourhood of Silwan, Space and Polity, 19 (2), 191-205.

MANSEL, P., 2016. Aleppo: the rise and fall of Syria's great merchant city. London: I.B. Tauris.

MiLHEM, R. 2017. Syria and China discuss means of boosting cultural cooperation. SA-

NA 17 May 2017. Accessed 20 May 2017. http://sana.sy/en/?p=106047

OECD, 2001. The DAC Guidelines: Helping Prevent Violent Conflict. Paris: OECD.

OrBAŞLI, A., 2013. Archaeological site management and local development. Conservation and Management of Archaeological Sites 15 (3-4), 237-53.

ORTALI-TARAZI, R., 2001-02. Loi et pratique dans la conservation du patrimoine culturel: le case des fouilles archéologiques dans le centre-ville de Beyrouth. ARAM Periodical 13-14: 355-358.

Ostry, J. D, P.LOUngani \& D. FurCeri, 2016. Neoliberalism oversold. Finance \& Development June 2016, 38-41.

Perring, D., 2009. Archaeology and the postwar reconstruction of Beirut. Conservation and Management of Archaeological Sites 11:3-4, 296-314.

Perring, D., Seeden, H., Sheehan, P. \& Williams, T., 1996. BEY 006, 1994-1995: The Souks Area: interim report of the AUB project. BAAL (Bulletin d'Archéologie et d'Architecture Libanaises) 1: 176-206.

PORTER, L. 2016. Photos reveal great damage to the mighty Aleppo. Telegraph 5 February 2016. Accessed 3 November 2016

http://www.telegraph.co.uk/travel/destinations/middle-east/syria/articles/Photos-

reveal-great-damage-to-mighty-Aleppo-Citadel/

PulLAN, W. \& M GWIAZDA, 2009. 'City of David': urban design and frontier heritage. Jerusalem Quarterly 39, 29-38.

Pyburn, K.A., 2014. Preservation as 'disaster capitalism': the downside of site rescue and the complexity of community engagement. Public Archaeology 13:1-3, 226-239.

RAGAB, T.S. 2011. The crisis of cultural identity in rehabilitating historic Beirutdowntown. Cities 28: 107-114.

RJOOB, A.A., 2009. The impact of Israeli Occupation on the conservation of cultural heritage sites in the Occupied Palestinian Territories: the case of 'salvage excavations'. Conservation and Management of Archaeological Sites 11(3-4), 214-35.

RuCK, J. 2016. Destruction of Aleppo: then and now - in pictures. The Guardian, $21^{\text {st }}$ December 2016. Accessed 22 December 2016

https://www.theguardian.com/world/2016/dec/21/aleppo-syria-war-destruction-thenand-now-in-pictures; accessed 10/05/17

SALIBI, K., 1988. A House of Many Mansions: the history of Lebanon reconsidered. London and New York: I.B. Tauris \& Co. Ltd.

SAndes, C.A., 2010. Archaeology, Conservation and the City: Post-Conflict Redevelopment in London, Berlin and Beirut. Oxford: Archaeopress. 
SANDES, C.A., 2013. Urban cultural heritage and armed conflict: the case of Beirut Central District, in: J. D. KILA \& J. A. ZEIDLER (eds.), Cultural Heritage in the Cross-Hairs: Protecting Cultural Property during Conflict. Leiden: Brill, 287-314.

SANDS, P., 2016. On Genocide and Trauma. Financial Times, $15^{\text {th }}$ April, 2016. Accessed 11 May 2017. https://www.ft.com/content/2ce55dee-01c7-11e6-ac98-3c15a1aa2e62

SADER, H., 2001. Lebanon's Heritage: will the past be part of the future?, in: A. NeUWIRTH \& P. Pflitsch (eds.), Crisis and Memory in Islamic Societies. Beirut: Ergon Verlag Würzburg in Kommission, 217-30.

SaAd, A. \& T. STellmach, 2010. Aleppo Diverse |Open City: an urban vision for 2025. Berlin: Uberbau.

SaAd, A. \& T. Stellmach, 2015. Aleppo 2025 City Development Strategy: a critical reflection, in R. SALIBA (ed.), Urban Design in the Arab World: reconceptualizing boundaries. London \& New York: Routledge, 115-140

SCHMID, H. 2006. Privatized urbanity or a politicized society? Reconstruction in Beirut after the Civil War. European Planning Studies 14 (3): 365-81.

SCHOFIELD, J., 1992. Recommendations concerning the future management of the archaeology of Beirut. Unpublished report, April 1992.

SCHOFIELD, J., 1994. Report of mission to co-ordinate archaeological work on the centre-ville Beirut Project $\left(17^{\text {th }}\right.$ September $-27^{\text {th }}$ September 1993). UNESCO, unpublished report.

SEEDEN, H., 2000. Lebanon's archaeological heritage on trial in Beirut: what future for Beirut's past?, in: McManamon F. P. \& A. HatTon (eds.), Cultural Resource Management in Contemporary Society: perspectives on managing and presenting the past. London and New York: Routledge, 168-87.

SEIF, A., 2009. Conceiving the past: fluctuations in a multi-value system. Conservation and Management of Archaeology Sites 11(3-4), 282-95.

SILBERMAN, N.A., 1991. Desolation and restoration: the impact of a Biblical concept on Near Eastern archaeology. The Biblical Archaeologist 54 (2): 76-87.

SILBERMAN, N.A, 2012. Changing visions of heritage value: what role should the experts play? Association francophone pour le savoir (ACFAS). Accessed 19 May 2017 https://works.bepress.com/neil_silberman/48/

Slater, T. 2009. Missing Marcuse: on gentrification and displacement. City 13 (2), 292311.

SOLIDERE, 2016. Archaeology. Accessed 15 November 2016

http://www.solidere.com/city-center/history-and-culture/archeology

StANLEY-PRICE, N. (ed.), 2007. Cultural Heritage in Postwar Recovery. Rome: ICCROM.

STRITCH, D., 2013. Contested archaeologies: archaeology in politics and identity formation, in C. Russell, L. HogAn \& M. JunKER-KENNY (eds.), Ethics for Graduate Researchers: a cross-disciplinary approach. London: Elsevier, 147-65.

Suchkov, M., 2017. What's Chechnya doing in Syria? Al-Monitor $26^{\text {th }}$ March 2017. Accessed 26 May 2017.

http://www.al-monitor.com/pulse/originals/2017/03/russia-syria-chechnya-ramzankadyrov-fighters.html

Tawakalna, I. \& Sharaf, N., 2005. Citadel of Aleppo. Damascus (publisher not identified). 
TMF, 2016. Turquoise Mountain. Accessed 15 November 2016

https://turquoisemountain.org/about

Throsby, D., 2012. The Economics of Cultural Policy. Cambridge: Cambridge University Press

UNESCO, 2011. Recommendation on the Historic Urban Landscape. Accessed 19 May

2016. http://portal.unesco.org/en/ev.php-

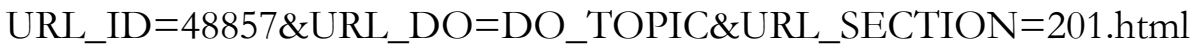

UNESCO, 2012. UNESCO Director-General deplores destruction of ancient Aleppo

markets, a World Heritage site. Accessed 12 May 2016.

http://www.unesco.org/new/en/social-and-human-sciences/themes/anti-

doping/sv15/news/unesco_director_general_deplores_destruction_of_ancient_alep/

UNESCO, 2014. Heritage and cultural diversity at risk in Iraq and Syria. UN Report. Accessed 12 May 2016. http://en.unesco.org/

UNESCO, 2016. Ancient City of Aleppo. Accessed 12 May 2016. http://whc.unesco.org/en/list/21.

UNESCO 2017a. UNESCO reports on extensive damage in first emergency assessment mission to Aleppo, Thursday, 19 January 2017. Accessed 20 January 2017. http://whc.unesco.org/en/news/1619/

UNESCO 2017b. UNESCO hosts First International Coordination Meeting for the recovery of Aleppo's heritage, Thursday, 9 March 2017. Accessed 10 March 2017. http://whc.unesco.org/en/news/1639/

UNESCO, United Nations Population Fund \& United Nations Development Programme, 2015. Post-2015 Dialogues on Culture and Development. Paris: UN.

UN, 2009. Agenda 21 Sustainable Development. Accessed 3 November 2016.

https://sustainabledevelopment.un.org/outcomedocuments/agenda21

UN Human Settlement Programme 2007. The State of Iraq Cities Report 2006/2007: cities in transition. Nairobi: UN.

UN General Assembly 2013. A/Res/68/223. Culture and sustainable development. Accessed 3 November 2016. http://research.un.org/en/docs/ga/quick/regular/68

Watenpaugh, K.D., 2006. Being Modern in the Middle East: revolution, nationalism, colonialism, and the Arab Middle Class. Princeton: Princeton University Press

WedGwood, T., 2009. History in two dimensions or three? Working class responses to history. International Journal of Heritage Studies, 15(4), 277-97.

WiLLIAMS, T., 2015. Archaeology: reading the city through time, in: F. BANDARIN \& R. VAN OERS (eds.), Reconnecting the City: the Historic Urban Landscape Approach and the Future of Urban Heritage. Chichester, West Sussex: John Wiley \& Sons Ltd, 19-46.

WORLD BANK, 2016a. Syria's economic outlook - Spring 2016. Accessed 1 December 2016.

http://www.worldbank.org/en/country/syria/publication/economic-outlook-spring2016

World BANK, 2016b. Syria Overview, $1^{\text {st }}$ October, 2016. Accessed 1 December 2016. http://www.worldbank.org/en/country/syria/overview.

WYNDHAM, C., 2015. Reconstructing Afghan identity: nation-building, international relations and the safeguarding of Afghanistan's Buddhist heritage, in: P. BASU \& W. MOD- 
EST (eds.), Museums, Heritage and International Development, London \& New York: Routledge, 122-42.

ZETTER, R., 2010. Land, housing and the reconstruction of the built environment, in: BARAKat, S. (ed.) After the Conflict: Reconstruction and Development in the Aftermath of War. London \& New York: I.B. Tauris (second edition), 155-72. 
